\author{
УДК 378.016:687.016 \\ DOI https://doi.org/10.32820/2074-8922-2019-64-164-176
}

\title{
ALGORITHM OF DEVELOPMENT OF INTERNATIONAL TRAINING PLAN FOR PREPARATION OF FASHION DESIGNERS WITH ACCOUNT OF INTERCULTURAL COMPETENCE FORMING CRyabchikova Katerina ${ }^{1}$, Nechipor Svitlana ${ }^{2}$ \\ AOD International Design Campus, Colombo, Sri Lankal Ukrainian Engineering Pedagogic Academy ${ }^{2}$
}

Інформація про автора:

Ryabchikova Katerina: ORCID 0000-0002-3086-5975; katryabchikova@gmail.com ; teacher, AOD International Design Campus, Colombo, Sri Lanka

Nechipor Svitlana: ORCID 0000-0003-3497-9889; nechiporsvetlana@i.ua ; PhD in Pedagogical Science, Associate Professor, Technology and Design, Ukrainian Engineering Pedagogics Academy, 16 Universitetska st/., Kharkiv,61003, Ukraine

The purpose of this article is to create common approaches to the development of curricula for the training of fashion designers, taking into account the formation of intercultural competencies on the basis of analysis of the basic functions of the activity, a systematic approach to the formation of general and special professional competencies, structural and logical links between the main modules that form competence. The main method in this case was the method of system analysis with nonlinear relationships in the formation of a complex of professional competencies, taking into account the intercultural component. The main criterion is the formation of basic descriptors in the form of knowledge, skills, communications, autonomy and responsibility. Based on the analysis of the curricula for the training of fashion designers in the countries of Europe, Asia, Africa, a non-linear system of forming integral competence has been developed that takes into account the provision of intercultural competence at different stages of preparation for effective work in conditions of other cultures or multicultural environments. The proposed system involves two levels of formation of intercultural competencies in the form of general professional and specially professional part. Formation of intercultural competence can be realized in the form of a sequential, parallel or non-linear elemental scheme. The basic competencies of a specialist in design of clothing are distinguished. They are composed of generally scientific competence, computer and information competence, cultural enlightenment competence, artistic competence, communicative competence with their intercultural parts in addition with common intercultural competence. Highest level include competence in choice of materials, projecting competence, technology competence, organization competence, business competence with their intercultural parts in addition with special intercultural competence. The presented competencies, in combination with intercultural components, are consistent with the main functions of the specialist in the field of design.

Key words: intercultural competence, fashion design, nonlinear system analysis.

Рябчикова К.М., Нечіпор С.В. «Алгоритм розробки міжнародного навчального плану підготовки fashion дизайнерів для формування міжкультурної компетентності».

Метою статті $є$ створення спільних підходів до розробки навчальних планів підготовки дизайнерів одягу з урахуванням формування міжкультурних компетентностей на основі аналізу основних функцій діяльності, системного підходу до формування загальних та спеціальних професійних компетентностей, структурних та логічних зв'язків між основними модулями, які формують компетентність. Основним методом у даному випадку був метод системного аналізу 3 нелінійними зв'язками при формуванні комплексу професійних компетентностей з урахуванням міжкультурної складової. Головним критерієм $€$ формування базових дескрипторів, таких як знання, уміння, комунікації, автономія та відповідальність. На основі аналізу навчальних програм підготовки дизайнерів моди в країнах Європи, Азії, Африки розроблена нелінійна система формування інтегральної компетентності, яка враховує забезпечення міжкультурної компетентності на різних етапах підготовки фахівця в умовах інших культур або багатокультурного середовища. Запропонована система передбачає два рівні формування міжкультурних компетентностей у формі загальної професійної та спеціальної професійної складової. Формування міжкультурної компетентності може бути реалізовано у вигляді послідовної, паралельної або нелінійної елементної 
схеми. Виділено основні компетентності фахівця 3 дизайну одягу. Вони складаються 3 загальнонаукової, комп'ютерної, інформаційної, культурологічної, художньої, комунікативної компетентностей з їх міжкультурними компонентами, а також загальної міжкультурної. Найвищий рівень включає компетентність у виборі матеріалів, проектувальну, технологічну, організаційну, ділову компетентності з їхніми міжкультурними складовими, а також особливу міжкультурну. Представлені компетентності, у поєднанні 3 міжкультурними компонентами, узгоджуються 3 основними функціями майбутнього фахівця у сфері дизайну.

Ключові слова: міжкультурна компетентність, fashion дизайн, нелінійний системний аналіз.

Рябчикова Е.Н., Нечипор С.В. «Алгоритм разработки международного учебного плана подготовки fashion дизайнеров для формирования межкультурной компетентности».

Целью статьи является создание совместных подходов к разработке учебных планов подготовки дизайнеров одежды с учётом формирования межкультурных компетенций на основе анализа основных функций деятельности, системного подхода к формированию общих и специальных профессиональных компетентностей, структурных и логических связей между основными модулями, которые формируют компетентность. Основным методом в данном случае был метод системного анализа с нелинейными связями при формировании комплекса профессиональных компетентностей с учётом межкультурной составляющей. Главным критерием является формирование базовых дескрипторов, таких как знания, умения, коммуникации, автономия и ответственность. На основе анализа учебных программ подготовки дизайнеров моды в странах Европы, Азии, Африки разработана нелинейная система формирования интегральной компетентности, которая учитывает обеспечение межкультурной компетентности на разных этапах подготовки специалиста в условиях других культур или поликультурной среды. Предложенная система предполагает два уровня формирования межкультурных компетенций в форме общей профессиональной и специальной профессиональной составляющей. Формирование межкультурной компетентности может быть реализовано в виде последовательной, параллельной или нелинейной элементной схемы. Выделены основные компетентности специалиста по дизайну одежды. Они состоят из общенаучной, компьютерной, информационной, культурологической, художественной, коммуникативной компетентности с их межкультурными компонентами, а также общей межкультурной. Самый высокий уровень включает компетентность в выборе материалов, проектировочную, технологическую, организационную, деловую компетентности с их межкультурными составляющими, a также особую межкультурную. Представленные компетентности, в сочетании с межкультурными компонентами, согласуются с основными функциями будущего специалиста в сфере дизайна.

Ключевые слова: межкультурная компетентность, fashion дизайн, нелинейный системный анализ.

\section{Problem statement in general.}

The globalization of higher education predetermines new approaches to the formation of curricula of various specialties. Probably one of the most sensitive industries that feel the influence of interculture is the «Fashion Design». Breaking cultural boundaries, fashion penetrates into different countries and cultures. Meanwhile, specialists working in this industry often feel the cultural pressure of a certain community, to which they were not prepared in the process of training. Similar problems arise also among specialists working in a multicultural team. And they can arise not only at the level of knowledge and skills, but, perhaps to a greater extent, at the level of communication, autonomy and responsibility, which determine the basic descriptors of a specialist's competence.
The solution to this problem is the formation of a specific intercultural competence of the specialist [1], which determines his ability to adapt to the conditions of work in different cultural groups.

The formation of intercultural competence is a multi factorial task. It includes intercultural forms of the organization of the educational process, videoconferences with representatives of other cultures, intercultural and international practices, and interethnic projects.

The basis for the formation of competence is the curriculum, which, in the context of globalization, should increasingly approach the notion of an «international curriculum».

This paper describes the experience of developing international plans for the specialty «Fashion design» in the Ukrainian Engineering Pedagogical 
Academy, taking into account the analysis of the curricula of several universities in Europe, Asia and Africa.

The study of literary sources showed that the actual introduction of intercultural competence into the educational process is largely the subject of philosophical discussions [2]. His article discusses a fundamental understanding of intercultural competence. The possible effects associated with the development of this competence among students are shown. Discussions led to the creation of a curriculum. It is expected that after training on this program, specialists will be able to work more effectively in multicultural firms. This article discusses the possibility of applying this training program.

It is noted in article [3] that many universities have begun to internationalize curricula. Such plans are aimed at developing intercultural competencies. The importance of such curricula is emphasized for students participating in mobility programs, as well as for students for whom mobility is not available for various reasons. It was noted that immobile students should also have access to intercultural competencies, which could further expand employment opportunities.

Knowledge, skills and communications that create intercultural competence are increasingly being requested by employers, as mandatory, especially if the work is related to multicultural communication. In article [4] the process of introducing a special course on the formation of intercultural skills in the curriculum is considered. The importance of integrating this course with courses that form other professional competencies, as well as the application of online teaching methods to expand access to the course, was noted.

Similar courses are offered in other works. So, Plakhotnik, M.S. [5], describes the course «Social and Cultural Foundations of Education». The development of intercultural competence in this case is based on auto-ethnography. This method of research determines the place of a person in the system of cultures, his social identity, and also helps build relationships with people of a different culture. The main cultural differences are religion, culture, national and ethnic identity.

Studies on the internationalization of curricula are held in universities of different countries. For example Dimitrov, N., Haque, A. [6], describe the process of formation of intercultural competencies in Canadian universities. The emphasis is on culturally relevant training. Students are tuned to orient in different groups or cultures. The authors call for the internationalization of curricula to take into account the growing cultural diversity of students.

Researchers in Germany May, D., Lensing, K., Tekkaya, A.E. [7], stressed that the field of formation of intercultural competence in universities determines a significant undeveloped potential. In particular, the analysis of university curricula showed insufficient number of modules related to international awareness.

The field of fashion design, in the opinion of many researchers has a special place in the problem of the formation of intercultural competencies. The reason for this is the global nature of the fashion industry, the relationship of the fashion industry and light industry in general throughout the world.

Portuguese sources on fashion design and marketing have outlined the prospects for the transition of fashion brands to international and intercultural social media [8].

At the universities of Mongolia, courses related to marketing and business of fashion, design and technology are allocated in the formation of curricula, the need to combine the ideas of engineering and art in the curricula of fashion design is determined [9]. In Chinese sources, it is assumed that the curricula should move towards an innovative interethnic and intercultural orientation [10].

Some researchers suggest that the curriculum includes the evolution of national identity in fashion design in an implicit external form in order to take into account the effects of modernization, globalization and competition among cultures [11].

A number of works describe the experience of partnership of different countries in the field of training fashion designers [12]. It is emphasized that the curriculum should be developed with intercultural programs in mind. Curricula and disciplines should take into account intercultural sensitivity, cultural intelligence, the formation of communicative intercultural skills.

The questions of including of various modules, themes and competencies in the curricula of fashion designers are described in study of Soetendorp, R. [13].

In general, it should be recognized that, despite a number of studies in the direction of the formation of intercultural competence of fashion designers, the creation of an algorithm for 
developing an international curriculum aimed at forming this competence is far from complete.

The purpose of this study is to develop common approaches to the development of curricula for the training of fashion designers, taking into account the formation of intercultural competencies on the basis of analysis of the basic functions of the activity, a systematic approach to the formation of general and special professional competencies, structural and logical links between the main modules that form competence.

Substantiation of the main competencies of the fashion designer.

In the European education system, the quality of a specialist is determined, first of all, by the acquired competencies [14]. The set of competencies for each specialty is determined by the main functions of the activity. The complex of competences forms the integral competence that for the specialty of fashion design can be defined in general terms, as the ability to solve complex specialized tasks and practical problems in the field of fashion design, which implies the application of certain theories and methods of science and art and is characterized by complexity and uncertainty conditions.

The integral professional competence of the future fashion designer (Fig. 1) implies the ability to create a harmonious image of a person, taking into account special conditions (features of a human figure, its color type, age, occupation, preferences, etc.). Such competence is characterized by the unity and dynamism of functional components.
The process of forming integral competence must consist of at least two stages. The first stage forms the general professional competencies, which are basic for the direction of «Design». The second stage forms the specific professional competencies that define the specialty «Fashion Design».

Formation of a complex of competencies is determined by a structurally logical scheme of the curriculum (Fig. 2), where separate training modules provide the formation of individual competencies. In this case, the study of a separate training module should be based on the previous module and provide for the formation of a certain intermediate competence. Formation of integral competence is completed in the process of executing the project's fashion design, which requires the implementation of a complex of preacquired competencies.

The structure obtained in Fig. 2 obviously corresponds to the basic properties of the system. It is characterized by integrity. This structure represents a single whole, aimed at achieving a certain goal. At the same time, it can be considered as a subsystem for a complex of specialties or part of a national education system.

The hierarchy of the structure of the system is determined by the presence of at least two elements. As a subsystem of the lower order, one can consider a complex of general professional competencies. Tasks of this level are subordinate to the tasks of the next level, which are determined by the structure of specific professional competencies.

Specific professional competence

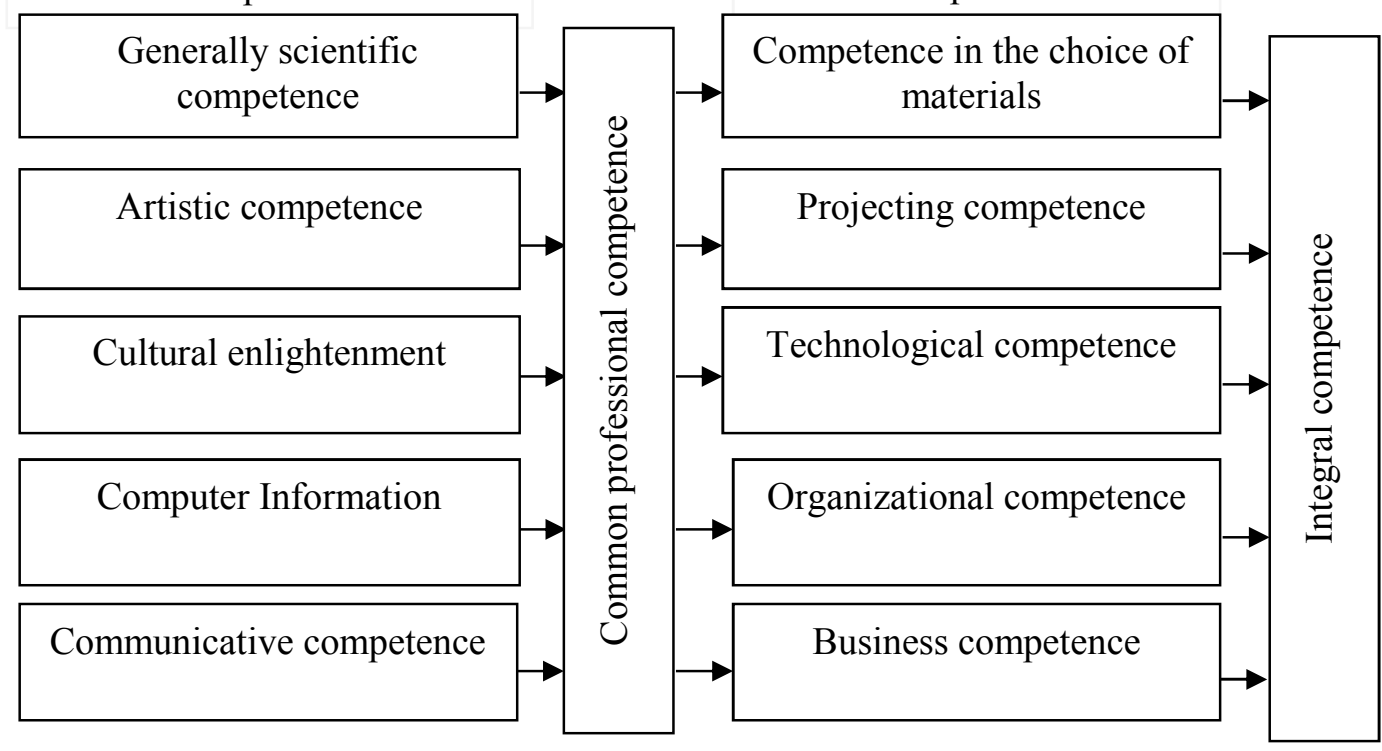

Fig.1 The order of formation of integral competence of the fashion designer 


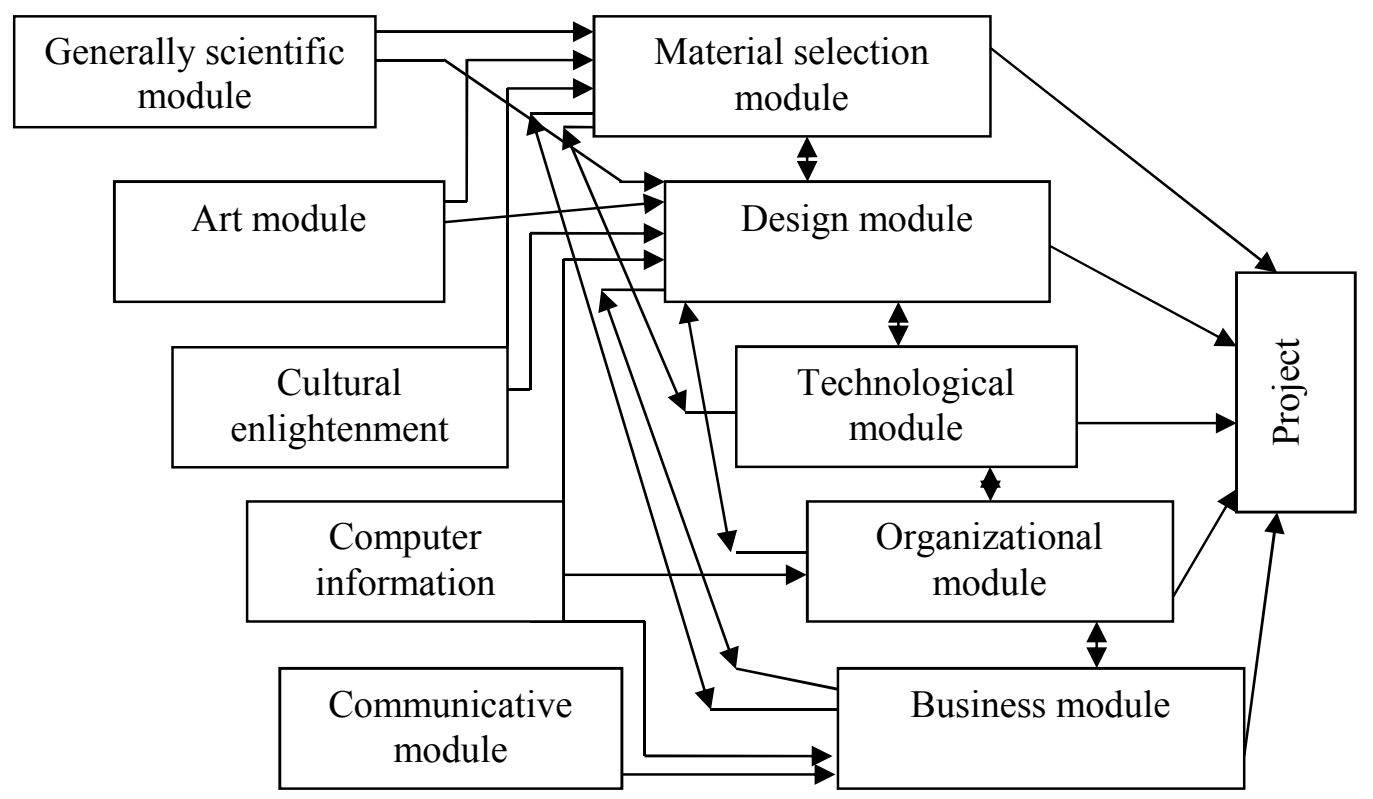

Fig.2 Simplified structurally logical scheme of training fashion designer

This system is characterized by structuring. Its properties are defined as the properties of individual components, and the properties of functional relationships.

The system approach was used by some researchers [15] for the scientific substantiation of the curriculum. The principles of a systematic approach are also inherent in the new Australian national program [16]. Modeling curriculum as a complex system is given in the work of Elena, F., Cristina, S., Petrua, M. [17].

A systematic approach to the analysis of such a system requires the study of several aspects that determine the feasibility and effectiveness of its functioning.

The system-functional aspect involves determining the basic functions that this system performs.

The study of the requirements of employers, the analysis of conditions that require the conditions of globalization determine the lack of competencies associated with the intercultural function of the activity, the opportunity to work in a multicultural environment, to use the features of other cultures in their activities in the direction of basic professional activities.

An additional intercultural function of a specialist's work necessarily requires the inclusion of additional elements in the general structure of the competence of a specialist.

In this case, depending on the nature of the aim function of the formation of integral competence taking into account the intercultural component the whole structure may vary.

A specific function of mastering of cultural features on the basis of the received national system of compression can be provided by the structure shown in Fig.3. Such a consistent scheme for the formation of intercultural competence is ensured by the introduction of special pre-diploma intercultural courses or professional internships in the curriculum. Functionally, such a scheme determines the selectivity of this competency in the curriculum for those who wish to work in a different culture.

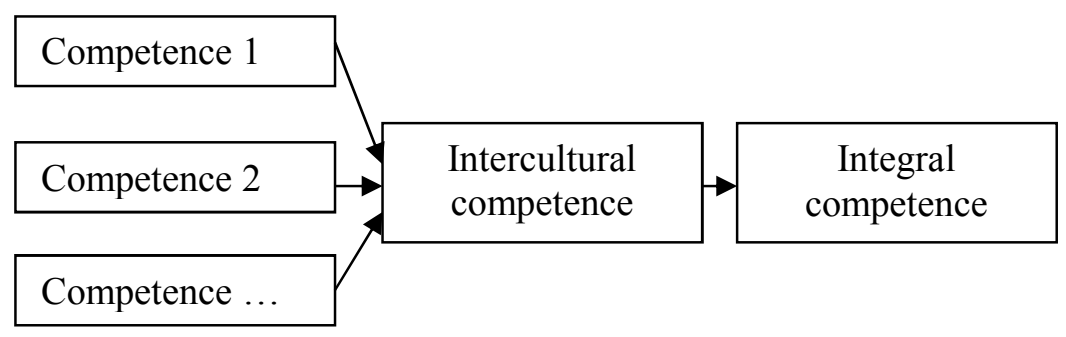

Fig.3 Consistent formation of intercultural competence 
Scheme with the parallel formation of intercultural competence is shown in Fig. 4. It can be provided with an additional compulsory general cultural course, for example, «Fashion design in poly cultural space», «Global fashion design», or compulsory vocational training in another culture.

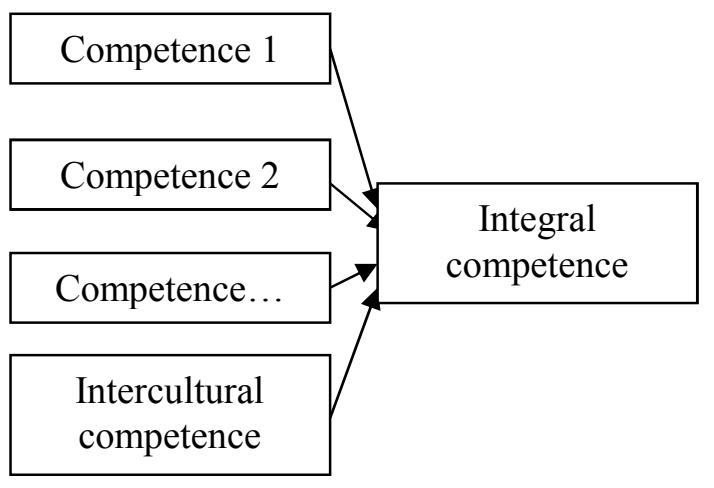

Fig.4 Parallel formation of intercultural competence

Possible scheme of formation of curriculum is shown on Fig. 5. At the same time intercultural competence in conditions of compulsory consideration of elements between culture in separate components or modules of the in the programs of separate disciplines it is necessary to enter the sections defining the intercultural orientation.

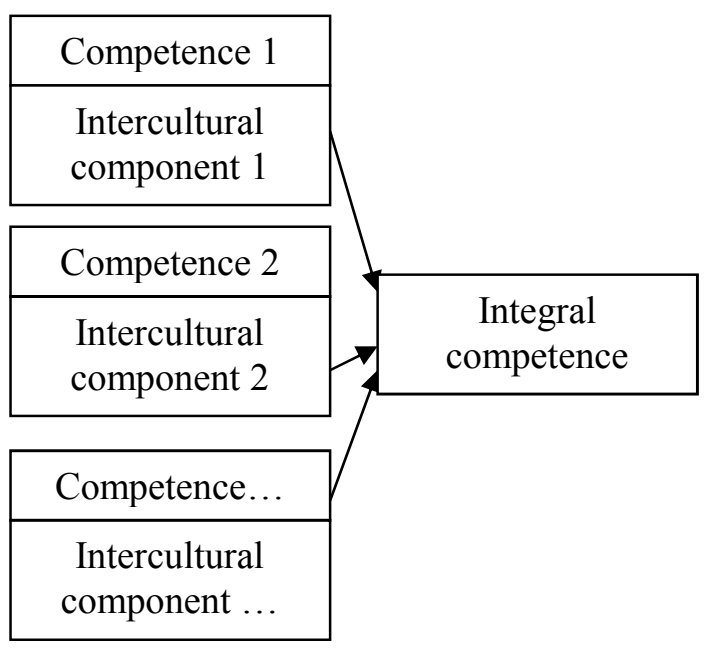

Fig.5 Non-linear elemental formation of intercultural competence

It should be noted that the use of the last scheme of Fig. 5 can lead to the emergence of complex nonlinear processes of intercultural components. In spite of the fact that nonlinear processes in the synthesis of curricula were investigated in some papers [18], [19] the real creation of such systems requires careful analysis.

In the following, some of the results of the analysis of the content of the training modules of the specialty «Fashion Design» on the basis of preparation of bachelors in the Ukrainian Engineering Pedagogical Academy in connection with cooperation agreements with the Liberec Technical University (Czech Republic), the
Academy of Design Arch Academy (Jaipur, India), Ethiopian Institute of Textile and Fashion Technology (EiTEX) Bahir Dar University (Ethiopia) are given. The analysis took into account the curricula of the Milan Academy of Fashion (Italian Republic), Kyiv University of Technology and Design (Ukraine), Tianjin Technical University (Chinese People's Republic). The results are presented in the form of a non-linear system of competencies, which are formed as a result of elemental introduction into courses programs in combination with successive and parallel processes of formation of intercultural competence. 
Formation of competences taking into account the intercultural component.

The nonlinear system of formation of intercultural competence for specialists of the specialty «Fashion Design» is presented in Fig. 6. Consider each of the components (Fig. 6), from the point of view of the possibility of forming the course of training future designers by means of disciplines.

The general scientific component of general professional competence involves the formation of the knowledge, skills and communications required by the future fashion designer and not related to the peculiarities of cultures of different countries. Typically, such a component is formed on the basis of the principles of personality development commonly accepted in all countries. Disciplines of the humanities, socio-economic direction and science-education provide the formation of the general-scientific component of the integral competence of the designer of clothing. We believe that the intercultural component in general scientific competence is present in a rather small proportion and does not generally require separate intercultural blocks.

The overall computer and information competence component also has requirements that are formed for the overall development and integration opportunities in the public space.
However, during designing of clothes, modern garment enterprises use automated designing systems for clothing (Assyst, PAD System, Gerber, Lectra, Investronica, Grafis, etc.), and different countries has their own software and features. The fashion designer, who has the experience of designing and development of collections of sewing products using clothes $\mathrm{CAD}$, will be able to adapt quickly to the conditions of production in different countries. In part, such a component of general professional competence can be attributed to the intercultural competence of the future designer.

Therefore, «Engineering and Computer Graphics», «Informatics and Computing» are the basic for such disciplines of a cycle of professional and practical training as «Computer Design», «Designing Clothing with Elements of CAD». The tasks of these disciplines are the formation of skills for the students to use the means of specialized computer software design to create collections of clothing, to develop color and spatial solutions to the design of clothing, the creation of bulk-spatial, plane artistic images («Computer Design»); constructing a design, introducing model changes in the cutting details, grading the layouts, and performing layout layouts on a fabric of a given width («Designing Clothing with Elements of $\mathrm{CAD} »)$.

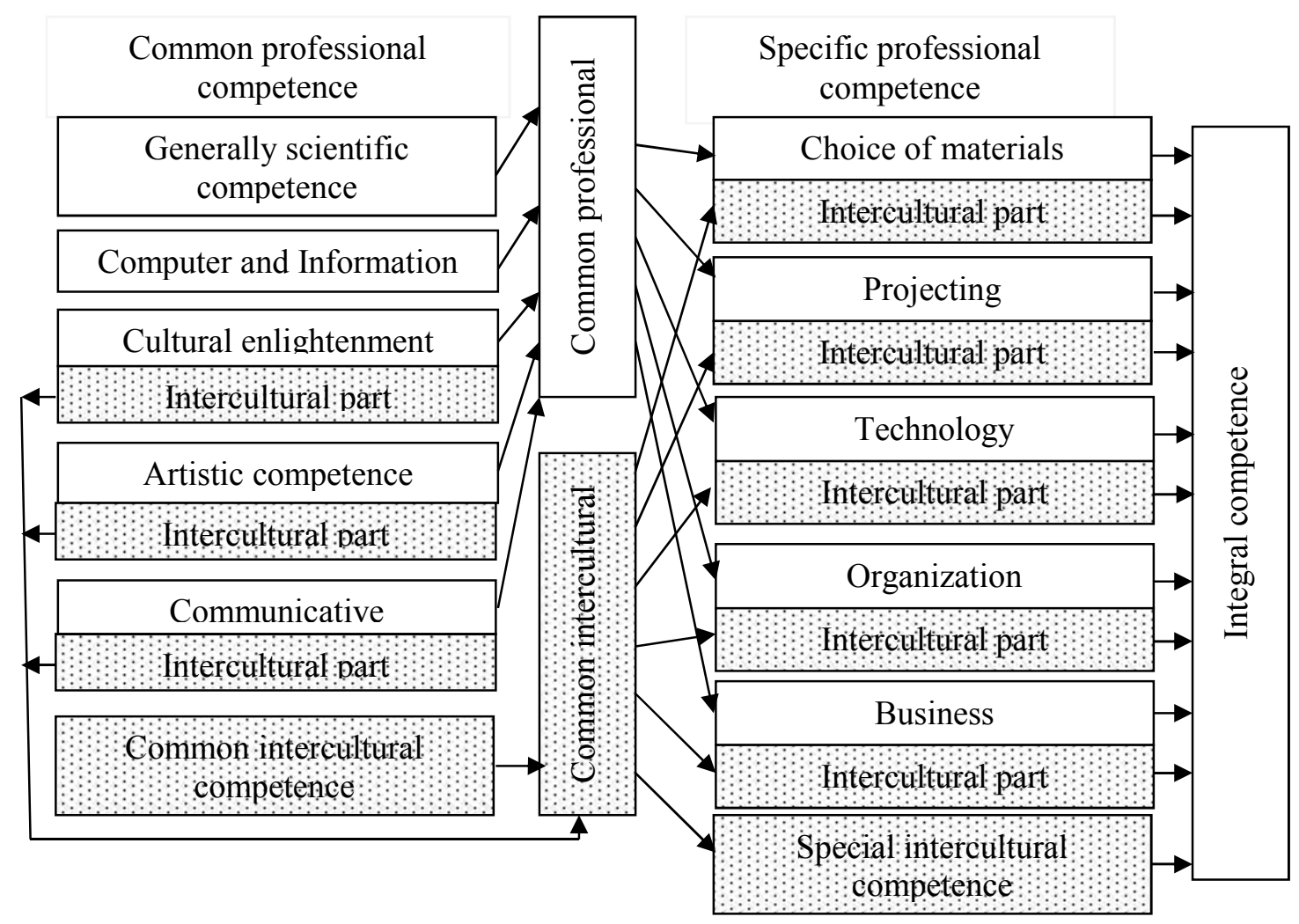

Fig.6 Structure of the formation of integral competence taking into account the intercultural component 
The artistic component of the integral competence of the future designer is the ability to be guided by the acquired artistic knowledge and skills, the willingness to use the experience gained in self-activity in accordance with universal human aesthetic values and own spiritual and philosophical positions [20], this universal characterization of the person of the artist who adheres to the laws, competently uses means and methods of harmonization of the work and constantly improves his skills [21].

Basic knowledge and skills in fine art are laid in the period of general secondary education (they are the basis of artistic competence), are used by the future designer for artistic perception and the use of previous experience to create an artistic image, which in our case is a complex image of a person.

The development of the artistic competence of the future fashion designer is ensured by studying such disciplines as Drawing and Plastic Anatomy, Painting and Fundamentals of Color Studies, Fundamentals of Artistic Design, Basics of Composition, etc.

The artistic component must take into account the peculiarities of the artistic culture of individual countries and may be provided by separate courses or sections of generally accepted courses.

The level of adaptability of the future designer to the cultural and artistic space of other countries indicates the development of the cultural and educational component of his overall competence. The task of disciplines on the development of such a component is the formation of a high degree of socialization and cultural education of the graduate who will allow him to communicate freely in the modern multicultural space, and, consequently, to freely apply his knowledge and skills when creating a design product for foreign countries. Obtaining of the national and universal values that are characteristic of different countries of the world for future designer is formed while teaching the discipline «History of the costume», «History of art and style». In the process of mastering art, future designers gain orientation skills in the cultural diversity of works of art, the realization of their art-study analysis and identification. It should take into account the need to study the peculiarities of the historical development of the style of different countries to this day.

Including in the target setting classes for the formation of intercultural competence can be exemplified, and more in depth explore the features of mentality, cultural views, natural and climatic features of different countries. Dividing conditionally the traditions of different cultures into the Eastern cultures (China, India, Japan, etc.) and the West (the countries of Europe, North America, Australia), it is clear that they differ not only in the territorial location, but also in world perceptions, value orientations, philosophy, religious and scientific views.

Thus, for example, the culture of the East has a steady historical development, while the culture of the West moves forward with jerks, distinct stages, periods with characteristic features of each of them.

Religious outlooks of the East are characterized by great diversity. Many religions come together. West - prefers Christianity.

In general, the East is irrational, and its culture is based on ancient customs. For the West is characterized by the shaking of traditions, rational, scientific knowledge of the world.

For the East is characterized by a «merger with nature», for the West, inherent "possession of nature».

In art in the countries of the East, immutable traditions are dominated, various types of arts «flow» one to the other. The West arts are characterized by a large variety of currents and styles, a rapid change of one another.

At the same time, each country has its own artistic (unofficial) symbols (signs, patterns, historical monuments, etc., which characterize them and according to which one can identify the country). For example, Japan has a symbolic meaning of sakura flower; China - animal panda. Egypt is famous for its pyramids; United States of America symbolizes the Statue of Liberty; France - the Eiffel Tower. Ukraine is famous for embroidered vestments.

Effectiveness of the dialogue of future designers at the level of multicultural communication depends on several factors: from the depth of understanding of the culture of the country; from the degree of tolerance (the ability of interlocutors to «listen» to each other and respond to his «cultural» requests); from the ability to find universal, common features of cultures that will allow finding a common language at the interstate level.

Formation of the communicative component of the intercultural competence of future fashion designers is a necessity that will enable not only fluent use of the language (including foreign ones), but also enrich the vocabulary with professional terms, correctly understand and 
competently express their thoughts in the native and foreign languages. And this is a guarantee of rapid integration into society, production, creative environment of designers. Such disciplines as «Foreign Language (for professional orientation)», «The Age and Professional Psychology», «Communicative Processes in Professional Activity», and «Rhetoric» are intended for the formation of communicative competence as a component of the integral competence of the future fashion designer. Awareness and understanding of texts in foreign languages, the ability to communicate with foreigners is an important manifestation of the emergence of intercultural competence of the future designer.

To form the integral competence of the future designer there are not enough general concepts that help to develop the personality, but also need to form specific professional components of competence, which include competence in the choice of materials, design, technology, organizational and business competence.

At first, students study the peculiarities of material science («Material Science of Sewing Products»). Competence in the choice of materials will be formed when future designers will be able to: identify the fiber content of the material, and this accordingly affects its properties; to understand the plasticity of a particular material, its texture and the possibilities of visual perception of the future design product from a particular type of material. The intercultural component of such competence is based on the study of the traditions of different countries: the characteristics of materials, their fiber content, methods of manufacturing, color gamut, invoice, etc.

The diversity in the use of materials is due to the history, geography, culture of different countries. Historically and traditionally, China is associated with silk, the home of cotton is considered to be India, linen cloths came from Assyria and Babylon, now traditionally used in Ukraine and Poland. In many countries, traditional national materials are preferred. In India, in many cases, jute is used, and Sri Lanka is determined by the significant release of coconut fiber fabrics. Fabrics based on fiber leaves of palm trees are made in Africa.

Traditional producers and exporters of wool are countries such as Australia, New Zealand, and Argentina.

Generally, the leaders in the production of various fabrics are Asian countries (China, South
Korea, India, etc.). At the same time, the standards of quality and generally the approaches to the quality of fabrics differ significantly, so consumers of materials from a certain fabric need to realize this fact.

The variety of designs of fabrics is also different. The bright colors of some cultures are different from the restrained tones of others. In many countries, they tend to be natural vegetable dyes, while others are based on synthetic dyeing.

The technological component of the future designer's competence implies the ability:

- to carry out the analysis of the conformity of the selected methods of technological processing to the properties of materials, features of technological requirements for sewing products of a certain range,

- substantiation of the choice of the parameters of the execution of stitches and seams when designing the technological process of making individual units of the product and product in general;

- the choice of modern equipment and devices for making a sewing product, which most closely matches the processing possibilities of a certain material.

The formation of the technological component of competence provides such disciplines as the training curriculum for the training of future designers of clothing such as «Technology of sewing products», «Apparel equipment», production training and practical training at specific workplaces in design studios, experimental research areas of clothing manufacturing enterprises.

Common approaches to clothing manufacturing technology are close in different cultures. Meanwhile, the difference in mass production, quality requirements, has its impact on technological processes. Well-known clothing brands in many cases place their production in other countries. At the same time, they are compelled to take into account the peculiarities of the technological process carried out at the enterprises of these countries or to introduce their own technologies.

The projecting component of the competence of the future fashion designer should be based on the comprehensive development of knowledge, skills and ability to generate design ideas for the implementation of collections of clothing. The designer should be able to:

- to develop a range of sewing products of a certain range;

- to develop designs of a garment; 
- to make patterns of the product;

- to carry out layouts of patterns of a sewing product on a fabric;

- to make a technological sequence of manufacturing a knot of a sewing product or a product in general.

Such disciplines as «Fundamentals of artistic design», «Designing of sewing products», «Modeling of clothes», «Typical design of clothing» should ensure the formation of design competence.

The general features of human figures, national traditions and rules of etiquette of each country influence the possibilities of artistic design and visual perception of the image.

The design of clothing is, perhaps the most visible area, in which you can see cultural, national, religious and other differences. Taking into account these differences in a multicultural environment is a prerequisite for the formation of a modern integral competence of a specialist.

When forming technological and design competence, special attention should be paid to the study of interstate, state and industry standards for the manufacture of clothing, which operate in different countries. Such knowledge will ensure the future designer avoids mistakes when promoting his design product to the market of different countries.

The organizational competence of the future designer lies in the ability to efficiently distribute and control the implementation of certain organizational tasks, coordination and business support of the professional activities of the members of the team; ability to plan their own and collective activities; the ability to unite creative people into groups and to trust them with knowledge and skills; the ability to manage change and make decisions, etc. This competence is formed by studying the disciplines «Business Economics and Marketing», «Psychology of Labor», «Jurisprudence», «Marketing and Merchandising». The intercultural component of such competence is the study of the traditions and peculiarities of management and organizational activity of different countries.

In the issues of formation of intercultural competence in different countries, it is necessary to take into account both national traditions and the specificity of national employment policies in different countries [22].

The national model of the organization of labor consists of a system of training and retraining, ways of regulating labor relations. The Japanese model, for example, is characterized by a deep connection between the worker and the place of work, the importance for the employee of the company's prestige [23].

In the US model, special attention is paid to training and retraining. Organizational policy priorities include the tasks of solving unemployment problems, developing human resources and labor relations. In the European system, the most flexible forms of organization are developed, which can sufficiently quickly react to changing market structure.

The development of private business is one of the foundations of economic development in different countries. Healthy competition, opening new jobs, expanding the consumer market, emerging in the market for new products and services should encourage the future designer to create a design product that will be competitive in the market.

Possibilities of the future designer as businessmen (business competence) depend on the level and quality of its economic, organizational preparation. Therefore, preparation of graduates for future entrepreneurial activity should ensure the adaptation of its activities in any country in the world. Therefore, during teaching of such disciplines as Marketing and Merchandising, Enterprise Economics and Marketing, special attention should be paid to studying how to create and promote an author's design product.

Based on the preliminary analysis of the possibility of forming various components of the integral competence of future fashion designers, the question arises: how to integrate the competences (or their components) formed into separate disciplines into one that will enable students to quickly integrate into the intercultural space of other countries.

From the point of view of intercultural competence, such competence should be considered as a single common, which is formed by means of educational disciplines and involves concentration in the study of the disciplines of integrated fashion design.

Such disciplines can be:

- «Fashion design in a multicultural space»;

- «Integrated design of clothes in the intercultural space»;

- «Global fashion education».

The result of studying such disciplines should be readiness [24]:

- to the analysis of project conditions and the formation of the project task (project design);

- to pre-design studies;

- to planning work on a design project; 
- to the formation of the artistic and design concept of the design project;

- to perform visualization of the artistic and design concept of a design project;

- to design and design of the design and technological part of the project;

- to the analysis of the results of design and project decisions, project activities;

- to the design support of the practical implementation of the design project.

When planning a work syllabus, one needs to take into account the complexity of the process of forming the intercultural competency of the future designer, as the process must go immediately to the creative level without passing through the reproductive level. Reproductive activity of the designer leads to the loss of his essence as the artist-creator.

Obligatory consolidation of integral competence and its intercultural component is diploma project. The subject of diploma projects should provide study of the culture of a particular country, especially stylistics, the development of a specific design product, taking into account the requirements for similar work in a particular country of the world.

One of the main areas of forming the integral competence of a specialist in the field of design, taking into account intercultural competence, should be the implementation of an international project to design collections of clothing by teams of students from several countries.

The input parameters for this project should include the professional competence, taking into account the intercultural component acquired in the previous stages, passing vocational training in a parallel scheme in order to form intercultural communicative competence. The project must be preceded by a special intercultural course (planned in the curriculum in a sequential scheme of competence development) with the wide introduction of virtual, mobile and other online communication methods between students of different cultures.

During developing of international curricula it should be borne in mind that the content of the training of future designers, taking into account the formation of intercultural competence, is the unity of theory and practice.

Such plans should be aimed at the formation of integral professional competence, which is provided by general professional and specifically professional components, and those in turn - the relevant components. The learning process should focus on the development of such components of the integral competence of the future designer who determine his ability to work in a globalized environment, while creating a design product that will meet the requirements of society and the scientific and technological progress of the consumer country.

However, the formation of competence does not end at the stage of obtaining a document on higher education. An important issue is the creation of a continuous system of design education, which should provide a high level of personal and professional development of the future fashion designer. The peculiarities of his professional activity include the harmonious development of the individual, constant work on the intellectual, creative and aesthetic level. This should be the subject of additional thorough research.

Conclusions and perspectives of further research.

On the base of analysis of training curricula for design students at the Ukrainian Engineering Pedagogical Academy, the Liberec Technical University (Czech Republic), the Academy Academy of Design Arch Academy (Jaipur, India), the Ethiopian Institute of Textile and Fashion Technology (EiTEX) Bahir Dar University (Ethiopia), the Milan Academy of Fashion (the Italian Republic), the Kyiv University of Technology and Design (Ukraine), Tianjin Technical University (Chinese People's Republic) the non-linear system of formation of integral competence, which takes into account the possibility of ensuring intercultural competence at different stages of preparation for the effective work of a specialist in conditions of other cultures or in multicultural environment is developed.

The proposed system involves two levels of formation of intercultural competencies in the form of general professional and specially professional part. Formation of intercultural competence can be realized in the form of a sequential, parallel or non-linear elemental scheme. The basic competencies of a specialist in design of clothing are distinguished. They are composed of generally scientific competence, computer and information competence, cultural enlightenment competence, artistic competence, communicative competence with their intercultural parts in addition with common intercultural competence. Highest level include competence in choice of materials, projecting competence, technology competence, organization competence, business competence with their 
intercultural parts in addition with special intercultural competence. The presented competencies, in combination with intercultural components, are consistent with the main functions of the specialist in the field of design.

The proposed nonlinear system of competency formation can be the basis for

\section{Список використаних джерел}

1. Deardorff D. K. Intercultural competence in higher education: International approaches, assessment and application / D. K. Deardorff, L. A. ArasaratnamSmith. - London : Routledge, 2017. - 312 p.

2. Punteney K. (2016) Deliberations on the development of an intercultural competence curriculum / K. Punteney // Intercultural Education. - 2016. - Vol. 27 (2). - Pp. 137-150.

3. Prieto-Flores Ò. Assessing Intercultural Competence as a Result of Internationalization at Home Efforts: A Case Study From the Nightingale Mentoring Program / Ò. Prieto-Flores, J. Feu, X. Casademont // Journal of Studies in International Education. - 2016. - Vol. 20 (5). - Pp. 437-453.

4. Taraban-Gordon S. Integrating intercultural competencies into the professional skills curriculum / S. Taraban-Gordon, E. Page // Promoting Intercultural Communication Competencies in Higher Education / Edited by G. M. Pérez, C. Rojas-Primus. - Hershey : Information Science Reference, 2016. - Pp. 19-139.

5. Plakhotnik M. S. Understanding social identity through autoethography: Building intercultural communication competencies in higher education classroom / M. S. Plakhotnik // Promoting Intercultural Communication Competencies in Higher Education / Edited by G. M. Pérez, C. Rojas-Primus. - Hershey : Information Science Reference, 2016. - Pp. 140-167.

6. Dimitrov N. Intercultural teaching competence in the disciplines: Teaching strategies for intercultural learning / N. Dimitrov, A. Haque // Promoting Intercultural Communication Competencies in Higher Education / Edited by G. M. Pérez, C. Rojas-Primus. - Hershey : Information Science Reference, 2016. - Pp. 89-118.

7. May D. Internationalization as a topic in higher engineering education: A quantitative content analysis examining the engineering curricula from ten German technical universities / D. May, K. Lensing, A. E. Tekkaya // IEEE Global Engineering Education Conference, EDUCON, 10-13 April, 2016. - Pp. 136-141.

8. Marques A. D. Learning process in fashion design students: Link with industry and social media / A. D. Marques, A. Moschatou // IOP Conference Series: Materials Science and Engineering. - 2017. No. 254 (23). - Pp. 232-235.

9. Lee J. Exploration of Textiles and Apparel Curriculum in Mongolia from the Academia and Industry Perspectives / J. Lee, E. Cho, E. Kim // Family and Consumer Sciences Research Journal. - 2017. No. 45 (4). - Pp. 345-362.

10. Tsui C. The evolution of the concept of 'design' in PRC Chinese academic discourse: A case of creating an international curriculum of specialists in the fashion design, taking into account the intercultural component, which will increase the efficiency of training specialists in the modern globalized world.

fashion design / C. Tsui // Journal of Design History. 2016. - Vol. 29 (4). - Pp. 405-426.

11. Tsui C. From symbols to spirit: Changing conceptions of national identity in chinese fashion / Tsui C. // Fashion Theory - Journal of Dress Body and Culture. - 2013. - Vol. 17(5). - Pp. 579-604.

12. Design thinking: Promoting diversity through global immersion / C. Beacham, N. M. MacDonald, J.-J. Yoo [et al.] // Family and Consumer Sciences Research Journal. - 2009. - Vol. 37 (3). - Pp. 344-358.

13. Soetendorp R. Teaching intellectual property to non-law students / R. Soetendorp // Teaching of Intellectual Property: Principles and Methods. - Cambridge : Cambridge University Press, 2008. - Pp. 230-267.

14. ECTS Users' Guide [Electronic resource] // European Union. - 2015. - 109 p. Access mode : http://ec.europa.eu/education/ects/usersguide/docs/ects-users-guide_en.pdf.

15. Buyurgan N. Déveloping a new industrial engineering curriculum using a systems engineering approach / N. Buyurgan, C. Kiassat // European Journal of Engineering Education. - 2017. - Vol. 42 (6). - Pp. 1263-1276.

16. Watt M. An evaluation of the Australian Government's Students First agenda for strengthening the curriculum / M. Watt // Curriculum Perspectives. 2017. - Vol. 37 (2). - Pp. 161-170.

17. Elena F. How to improve curriculum development through processes modeling technique / F. Elena, S. Cristina, M. Petrua // International Multidisciplinary Scientific GeoConference Surveying Geology and Mining Ecology Management. - 2017. Vol. 17 (54). - Pp. 73-80.

18. Teaching for equity: insights from international evidence with implications for a teacher education curriculum / L. Grudnoff, M. Haigh, M. Hill [et al.] // Curriculum Journal/ - 2017. - Vol. 28 (3). - Pp. 305-326.

19. Ryabchikova K. Competency-build approach to the unitizing of vocational schools / K. Ryabchikova // International Conference on Interactive Collaborative Learning (ICL) 20-24 Sept. - Florence: Italy, 2015. - Pp. 471-476.

20. Zakirova V. G. Creative environment formation in design professional training / V. G. Zakirova, E. E. Purik // International Journal of Environmental and Science Education. - 2016. - Vol. 11 (9). - Pp. 2323-2332.

21. Kroflič R. The role of artistic experiences in the comprehensive inductive educational approach / R. Kroflič // Pastoral Care in Education. - 2012. - Vol. 30 (3). - Pp. 263-280. 
22. National employment policies: A guide for workers' organisations. - Geneva: International Labour Organization, 2015. $-27 \mathrm{p}$.

23. Yoshio Higuchi Promoting employability in the context of globalisation in the EU and Japan / Yoshio Higuchi // 11th eu-japan symposium (20-21 March). - Brussels, 2006. - Pp. 1-28.

24. Budkeev S. M. (2016) Students-designers' professional competencies formation by means of folk arts and crafts / S. M. Budkeev, J. V. Kiryushina, L.V. Shokorovaa // International Journal of Environmental and Science Education. - 2016. - Iss. 261. - Pp. 3394-3405.

\section{References}

1. Deardorff, DK \& Arasaratnam-Smith, LA 2017, Intercultural competence in higher education: International approaches, assessment and application, Routledge, London.

2. Punteney, K 2016, 'Deliberations on the development of an intercultural competence curriculum', Intercultural Education, no. 27 (2), pp. 137-150.

3. Prieto-Flores, Ò, Feu, J \& Casademont, X 2016, 'Assessing Intercultural Competence as a Result of Internationalization at Home Efforts: A Case Study From the Nightingale Mentoring Program', Journal of Studies in International Education, no. 20 (5), pp. 437-453.

4. Taraban-Gordon, S \& Page, E 2016, 'Integrating intercultural competencies into the professional skills curriculum', Promoting Intercultural Communication Competencies in Higher Education, Information Science Reference, Hershey, pp. 19-139.

5. Plakhotnik, MS 2016, 'Understanding social identity through autoethography: Building intercultural communication competencies in higher education classroom', Promoting Intercultural Communication Competencies in Higher Education, Information Science Reference, Hershey, pp. 140-167.

6. Dimitrov, N \& Haque, A 2016, 'Intercultural teaching competence in the disciplines: Teaching strategies for intercultural learning', Promoting Intercultural Communication Competencies in Higher Education, Information Science Reference, Hershey, pp. 89-118.

7. May, D, Lensing, K \& Tekkaya, AE 2016, 'Internationalization as a topic in higher engineering education: A quantitative content analysis examining the engineering curricula from ten German technical universities', IEEE Global Engineering Education Conference, EDUCON, 10-13-April-2016,7474544, pp. 136-141.

8. Marques, AD \& Moschatou, A 2017, 'Learning process in fashion design students: Link with industry and social media', IOP Conference Series: Materials Science and Engineering, no. 254 (23), pp. 232-235.

9. Lee, J, Cho, E \& Kim, E 2017, 'Exploration of Textiles and Apparel Curriculum in Mongolia from the Academia and Industry Perspectives', Family and Consumer Sciences Research Journal, no. 45 (4), pp. 345-362.

10. Tsui, C 2016, 'The evolution of the concept of 'design' in PRC Chinese academic discourse: A case of fashion design', Journal of Design History, no. 29 (4), pp. 405-426.

11. Tsui, C 2013, 'From symbols to spirit: Changing conceptions of national identity in chinese fashion', Fashion Theory - Journal of Dress Body and Culture, no. 17 (5), pp. 579-604.

12. Beacham, C, MacDonald, NM, Yoo, J.-J \& McFall, BS 2009, 'Design thinking: Promoting diversity through global immersion', Family and Consumer Sciences Research Journal, no. 37 (3), pp. 344-358.

13. Soetendorp, R 2008, 'Teaching intellectual property to non-law students', Teaching of Intellectual Property: Principles and Methods, Cambridge University Press, Cambridge, pp.230-267.

14. ECTS Users' Guide 2015, European Union, viewed 01 April 2019, <http://ec.europa.eu/education/ ects/users-guide/docs/ects-users-guide_en.pdf $>$.

15. Buyurgan, N \& Kiassat, C 2017, 'Developing a new industrial engineering curriculum using a systems engineering approach', European Journal of Engineering Education, no. 42 (6), pp. 1263-1276.

16. Watt, M 2017, 'An evaluation of the Australian Government's Students First agenda for strengthening the curriculum', Curriculum Perspectives, no. 37 (2), pp. 161-170.

17. Elena, F, Cristina, S \& Petrua, M 2017, 'How to improve curriculum development through processes modeling technique', International Multidisciplinary Scientific GeoConference Surveying Geology and Mining Ecology Management, SGEM, no. 17 (54), pp. 73-80.

18. Grudnoff, L, Haigh, M, Hill, M, Ell, F \& Ludlow, L 2017, 'Teaching for equity: insights from international evidence with implications for a teacher education curriculum', Curriculum Journal, no. 28 (3), pp. $305-326$.

19. Ryabchikova, K 2015, 'Competency-build approach to the unitizing of vocational schools', International Conference on Interactive Collaborative Learning (ICL), 20-24 Sept. 2015 Florence, pp. 471-476.

20. Zakirova, VG \& Purik, EE 2016, 'Creative environment formation in design professional training', International Journal of Environmental and Science Education, no. 11 (9), pp. 2323-2332.

21. Kroflič, R 2012, 'The role of artistic experiences in the comprehensive inductive educational approach', Pastoral Care in Education, no. 30 (3), pp. 263-280.

22. National employment policies 2015, A guide for workers' organisations, International Labour Organization, Geneva, pp.1-27.

23. Yoshio Higuchi 2006, 'Promoting employability in the context of globalisation in the EU and Japan', 11th eu-japan symposium 20-21 March 2006, Brussels, pp.1-28.

24. Budkeev, SM, Kiryushina, JV \& Shokorovaa, LV 2016, 'Students-designers' professional competencies formation by means of folk arts and crafts', International Journal of Environmental and Science Education, iss.261, pp. 3394-3405.

Стаття надійшла до редакиії 24.05.2019 р. 